\title{
研究ノート
}

\section{4-アミノ酪酸富化食品用玄米を生産するための品種選定 および追肥と収穫時期の検討}

\author{
三枝貴代 ${ }^{1,3 *}$ ，石川哲也 ${ }^{1,4}$ ，樋口浩二 ${ }^{2}$ ，石田元彦 ${ }^{1,5}$ \\ ${ }^{1}$ 国立研究開発法人農業・食品産業技術総合研究機構中央農業総合研究センター \\ 2 国立研究開発法人農業・食品産業総合研究機構畜産草地研究所 \\ 3 現所属 国立研究開発法人農業・食品産業技術総合研究機構作物研究所 \\ ${ }^{4}$ 現所属 国立研究開発法人農業・食品産業技術総合研究機構東北農業研究センター \\ ${ }^{5}$ 現所属 石川県立大学生物資源環境学研究科
}

Effects of Rice Cultivar, Additional Fertilizer Application, and Harvest Time on 4-aminobutyric Acid (GABA) Content of Brown Rice :

Potential Improvements to GABA-enriched Supplementary Foods

Takayo Saikusa ${ }^{1,3 *}$, Tetsuya Ishikawa ${ }^{1,4}$, Kouji Higuchi $^{2}$ and Motohiko Ishida ${ }^{1,5}$

${ }^{1}$ NARO Agricultural Research Center, Tsukuba 305-8666

${ }^{2}$ NARO Institute of Livestock and Grassland Science, Tsukuba 305-0901

${ }^{3}$ Present address : NARO Institute of Crop Science, Tsukuba 305-8518

${ }^{4}$ Present address : NARO Tohoku Agricultural Research Center, Fukushima 960-2156

${ }^{5}$ Present address : Bioresources and Environmental Science, Ishikawa Prefectural University, Ishikawa 921-8836

\begin{abstract}
There is considerable demand for 4-aminobutyric acid (GABA)-enriched brown rice because GABA effectively decreases blood pressure and improves mental stability. We examined the effect of early harvesting and additional fertilizer application on the GABA content of rice cultivars with various genetic backgrounds-data applicable to the production of GABA-enriched processed rice foods. Early harvesting and additional fertilizer application at the panicle formation stage or at the full heading stage did not lead to an increase in GABA contents. However, large variations in GABA accumulation were observed among the different cultivars, and one (cv. Bekogonomi) was able to accumulate $40 \mathrm{mg} / 100 \mathrm{~g}$ of GABA. This result suggests that it is possible to develop new GABA-enriched rice cultivars without a large germ for the supplementary health food sector.
\end{abstract}

(Received Apr. 2, 2015 ; Accepted Jun. 8, 2015)

Keywords : 4-aminobutyric acid (GABA), brown rice, cultivars, additional fertilizer, early harvesting キーワード: GABA，玄米，品種，追肥，早杊り

著者らは 1994 年, 米を水に浸漬することによって, 4-ア ミノ酪酸（GABA）が大量に生成, 蓄積することを発見し た ${ }^{11}$. GABA は高等植物において機械的刺激や低温, 低酸 素, 乾燥など, ストレスに対する応答として細胞内に流入 するカルシウムイオンによって活性化するグルタミン酸脱 炭酸酵素 (GAD) の作用で, グルタミン酸からの一分子脱 炭酸反応が起こることによって生成する ${ }^{2)}$. . GABA は哺 乳動物においては抑制系神経伝達物質であり, 経口摂取に より高血圧抑制効果 ${ }^{5}$ や や, 不眠や抑徭への緩和効果 ${ }^{677)}$ があ ることが知られており, GABA を蓄積させた加工食品は機
能性を期待して多種製造販売されている．特に発芽玄米8 や高圧処理玄米 ${ }^{910)}$ は白米に混ぜて手軽に炊飯できること と, GABA のほかに食物繊維なども摂取でき肥満抑制効果 も期待できる食品として需要が高い。これらの加工技術に ついては多くの研究が行われているが ${ }^{1112)}$, 原料米品種の選 定にあたっては巨大胚芽米の利用が一部で試みられてい る ${ }^{13) 14)}$ ほかには専用品種が存在しない. そこで今回我々 は, GABA を蓄積させる目的で栽培した玄米について, GABA 蓄積量に対する早杊りや窒素肥料追肥の影響およ び品種選定の可能性について検討した. 


\begin{tabular}{|c|c|c|c|c|c|c|c|c|c|c|}
\hline \multirow{2}{*}{$\begin{array}{c}\text { 水浸漬時間 } \\
(\mathrm{hr})^{*}\end{array}$} & \multicolumn{2}{|c|}{ タカナリ } & \multicolumn{2}{|c|}{ ふくひびき } & \multicolumn{2}{|c|}{ 奥羽飼 394 号 } & \multicolumn{2}{|c|}{ ベこごのみ } & \multicolumn{2}{|c|}{ 夢あおば } \\
\hline & 早刈 & 完熟期杊 & 早刈 & 完熟期刚 & 早杊 & 完熟期刚 & 早刈 & 完熟期刚 & 早刈 & 完熟期刚 \\
\hline 0 & 3.3 & 1.4 & 7.4 & 5.6 & 9.2 & 4.7 & 13.3 & 18.7 & 4.1 & 3.1 \\
\hline 4 & 7.7 & 4.8 & 12.6 & 14.3 & 14.0 & 15.6 & 21.9 & 20.6 & 10.6 & 10.6 \\
\hline 24 & 3.7 & 6.0 & 15.2 & 16.6 & & & & & 2.8 & 13.1 \\
\hline
\end{tabular}

*水浸漬処理は $40^{\circ} \mathrm{C}$ で行った。

\section{1. 実験方法}

（1）供試材料

玄米はすべて茨城県つくばみらい市の中央農業総合研究 センター谷和原水田戋場で栽培した水稲から得た。収穫 後, 稲袈かけにより乾燥, 脱穀し, 籾摺後に $1.8 \mathrm{~mm}$ で篩選 し，供試まで $4^{\circ} \mathrm{C} て ゙$ 保管した。

収穫時期の影響を確認する実験に供試した，タカナリ， ふくひびき, 奥羽飼 394 号, ベこごのみ, 夢あおばは 2005 年 に，基肥なし条件および基肥多肥条件下での追肥の影響を 確認する実験に供試した，ふくひびき，べこごのみは 2006 年に，それぞれ移植条件で栽培した。基肥標準条件下での 追肥の影響を確認する実験に供試した，べこあおば，モミ ロマンの栽培は 2007 年に湛水直播条件で栽培した。試験 に用いた品種は全て胚芽の大きさは標準範囲内（玄米中の 胚芽重量比が 2 3\% 前後) であり, 巨大肧芽米ではない.

(2) 収穫時期

いずれの品種も出穂後 5 週間後を目安に， 5 割程度の籾 が黄化し玄米が透明になった時期(黄熟期)に早刈りを行っ た。完熟期㺫りは，その 1 週間後, ほとんどの籾が黄化し, 玄米の 9 割程度が緑色を失った時期に行った。

（3）施肥条件

2005 年は，基肥として高度化成を用いて窒素 $7.0 \mathrm{~kg} / 10 \mathrm{a}$ を施用し，幼穂形成期に NK 化成を用いて窒素 $5.1 \mathrm{~kg} / 10 \mathrm{a}$ を追肥した。

2006 年は，基肥なし区では基肥を施用せず，多肥（基肥 多肥十幼穂形成期追肥）区では基肥として高度化成を用い て窒素 $7.0 \mathrm{~kg} / 10 \mathrm{a}$ を施用し, 幼穂形成期に NK 化成を用い て窒素 $5.1 \mathrm{~kg} / 10 \mathrm{a}$ を追肥した。いずれも穂揃期に硫安を 用いて $2.1 \mathrm{~kg} / 10 \mathrm{a}$ を追肥する試験区（基肥なし十追肥区, 多肥十追肥区）を設けた。

2007 年は, 基肥として被覆尿素肥料を用いて窒素 8.3 $\mathrm{kg} / 10 \mathrm{a}$ を施用した。ささらに幼穂形成期に NK 化成を用い て窒素を $3.4 \mathrm{~kg} / 10 \mathrm{a}$ 追肥する試験区（基肥標準＋追肥区） を設けた

(4) GABA 蓄積量測定方法

玄米は目開き $0.5 \mathrm{~mm}$ のふるいをつけた遠心式粉砕器 (pulluerisette 14, FRITSCH, ドイツ) で粉砕し, $1.00 \mathrm{~g}$ を秤 量，ねじ口つき試験管に入れ，蒸留水を $4.00 \mathrm{ml}$ 加えた。蓋 をした試験管を恒温振とう槽（パーソナル $11 \cdot \mathrm{SDN}$, TAITEC, 埼玉) に設置し, ゆるい振とうを行いつつ $40^{\circ} \mathrm{C}$
で保管，0，4，24 時間後 $40 \%(\mathrm{w} / \mathrm{v} ）$ トリクロロ酢酸水溶 液を $1.00 \mathrm{ml}$ 加えて撹拌，酵素反応を停止した。

この混濁液をろ紙（No.2，ADVANTEC，東京）と 0.45 $\mu \mathrm{m}$ 孔のセルロースアセテートフィルターユニット (DISMIC 25CS045AN，ADVANTEC，東京）でろ過後，ア ミノ酸アナライザー（L-8500, 日立ハイテクノロジーズ, 東京）にイオン交換カラム（P/N855-3501，4.6 mmID ×6.0 $\mathrm{mm}$ ，三菱化成，東京）を接続，クエン酸リチウム緩衝液を 用いる生体液分析プログラムにて GABA を定量した。

玄米は $115^{\circ} \mathrm{C}, 12$ 時間乾燥し, 重量法で水分率を計算, GABA 蓄積量を計算した

測定は，いずれも収穫後一年以内に，同じ年の試料は常 に同時に行った。

\section{2. 実験結果および考察}

（1）収穫時期による影響

早㺫りでの GABA 蓄積量と完熟期刚りでの GABA 蓄積 量を表 1 に示した。早刈りによって, GABA 蓄積量の増大 は確認されなかった。

玄米中の GABA は水浸漬により，米粒内に元々存在し ていた遊離グルタミン酸の量よりも多く蓄積する場合があ る1!.これは GABA の蓄積に GAD 以外にプロテアーゼや ペプチダーゼなどのタンパク質分解酵素などが深く係わっ ていることを示している。原料保管中に GABA 生成に係 わる各種酵素の活性が低下することによって GABA 蓄積 量が低下する現象は，米に限らず多くの GABA 富化食品 の製造現場で観察されており，米も鮮度が高いほど多くの GABA を蓄積する可能性が高いことが推定される。一方, イネは完熟より10 日収穫の早い早刈りによって澱粉分解 酵素の活性が高い米を収穫することができ，それによって 炊飯後の白米の甘みが増す現象が報告されている ${ }^{15}$. GABA 蓄積に関与する酵素も早刈りによって高い活性が 予想され GABA 蓄積量が増大することを期待したが, GABA 蓄積量は大きく変動しなかった。米粒において GABA は水浸漬中に生合成されるのみでなく, 分解もされ ており ${ }^{16)}$ 最終的な蓄積量は合成量から分解量を差し引い た量に相当する。GABAの蓄積は多くの酵素が複雑に関 与する現象であるため, 早刈りによる単純な蓄積量増大は 起こらなかったものと考える。

（2）追肥による影響

基肥なし条件下および多肥(基肥多肥十幼穂形成期追肥) 
表 2 玄米の水浸漬による GABA 蓄積量への穂揃期追肥の影響と玄米収量 基肥なしあるいは多肥（基肥多肥十幼穂形成期追肥）条件において

\begin{tabular}{|c|c|c|c|c|c|c|c|c|c|}
\hline & \multirow{2}{*}{$\begin{array}{c}\text { 水浸漬時間 } \\
(\mathrm{hr})^{*}\end{array}$} & \multicolumn{4}{|c|}{ ベこごのみ } & \multicolumn{4}{|c|}{ ふくひびき } \\
\hline & & 基肥なし区 & $\begin{array}{l}\text { 基肥なし } \\
\text { +追肥区 }\end{array}$ & 多肥区 & $\begin{array}{c}\text { 多肥 } \\
+ \text { 追肥区 }\end{array}$ & 基肥なし区 & $\begin{array}{l}\text { 基肥なし } \\
+ \text { +追肥区 }\end{array}$ & 多肥区 & $\begin{array}{c}\text { 多肥 } \\
+ \text { 追肥区 }\end{array}$ \\
\hline \multirow{3}{*}{$\begin{array}{l}\text { GABA 蓄積量 } \\
(\mathrm{mg} / 100 \mathrm{~g})\end{array}$} & 0 & 2.6 & 2.4 & 10.5 & 9.1 & 3.2 & 4.0 & 3.6 & 3.4 \\
\hline & 4 & 11.3 & 10.9 & 23.2 & 21.7 & 32.9 & 31.3 & 30.4 & 16.2 \\
\hline & 24 & 28.1 & 40.6 & 44.3 & 47.5 & 13.0 & 25.6 & 2.9 & 17.1 \\
\hline \multicolumn{2}{|c|}{ 玄米収量 $(\mathrm{kg} / 10 \mathrm{a})^{* *}$} & 509 & 502 & 599 & 587 & 437 & 420 & 720 & 730 \\
\hline
\end{tabular}

* 水浸漬処理は $40^{\circ} \mathrm{C}$ で行った

**ベこごのみは一部鳥害を被った。

表 3 玄米の水浸漬による $\mathrm{GABA}$ 蓄積量への基肥標準条件における幼穂形成期での 追肥の影響と，玄米収量

\begin{tabular}{|c|c|c|c|c|c|}
\hline & \multirow{2}{*}{$\begin{array}{c}\text { 水浸漬時間 } \\
(\mathrm{hr})^{*}\end{array}$} & \multicolumn{2}{|c|}{ ベこあおば } & \multicolumn{2}{|c|}{ モミロマン } \\
\hline & & 基肥標準区 & $\begin{array}{l}\text { 基肥標準 } \\
+ \text { +追肥区 }\end{array}$ & 基肥標準区 & $\begin{array}{l}\text { 基肥標準 } \\
+ \text { +追肥区 }\end{array}$ \\
\hline \multirow{3}{*}{$\begin{array}{l}\text { GABA 蓄積量 } \\
(\mathrm{mg} / 100 \mathrm{~g})\end{array}$} & 0 & 0.3 & 0.9 & 1.3 & 1.7 \\
\hline & 4 & 2.2 & 2.6 & 4.4 & 3.6 \\
\hline & 24 & 1.7 & 1.9 & 15.2 & 6.8 \\
\hline \multicolumn{2}{|c|}{ 玄米収量（kg/10a） } & 439 & 693 & 492 & 515 \\
\hline
\end{tabular}

条件下での穂揃期での追肥が GABA 蓄積量におよぼす影 響について表 2 に示した。基肥なし条件では追肥が GABA 蓄積量の増大に効果があるように見えたが，多肥条件では 追肥を行っても GABA 蓄積量が増加せず, ふくひびきで は多肥条件下での追肥はむしろ GABA 蓄積量を減らした。 また，穂揃期の追肥は収量の増大に寄与しなかった。

穂揃期の追肥は収量の増大に寄与しなかったので，追肥 した窒素はタンパク質などの窒素化合物として米粒中に蓄 積した可能性が高い。従って基肥なし条件では, 不足して いた米粒中のタンパク質含量が穂揃期の追肥によって補わ れた事によるGABA 蓄積量の増大があった可能性が考え られる。しかし多肥条件では, GABAの合成に関与する酵 素だけでなく分解に関与する酵素も増大したからか，ある いは追肥がプロラミンのように水浸漬後すぐには分解しな い窒素化合物の増大にのみ寄与したためか, GABA 蓄積量 は増大しなかった。しかし建部ら ${ }^{17)}$ の報告によれば，施肥 条件によってプロラミン含量割合の変動は確認されていな いため，追肥によって特定のタンパク質のみの増大の可能 性はあまりないものと考えられるため, 増大した窒素化合 物がプロラミンだけであった可能性は低いと推定される.

基肥標準施肥での幼穂形成期での追肥が GABA 蓄積量 におよぼす影響について表 3 に示した。ここでも追肥は GABA 蓄積量の増大に寄与しなかった。また, モミロマン では追肥がむしろ GABA 蓄積量を減少させる傾向があっ た。
追肥を幼穂形成期に行った場合，玄米中のタンパク質含 量は増大せず，玄米収量のみが増加することが知られてい る ${ }^{18)}$. 表 3 に示した通り，幼穂形成期の追肥は収量増大に 寄与したが，種子中のタンパク質含量増大にはあまり寄与 しなかったため GABA 蓄積量に追肥の影響が大きくな かったのではないかと推定された

追肥が玄米中のタンパク質含量をあげる効果は，追肥の 時期によって大きく異なる ${ }^{1920)}$. GABA 蓄積量を増大させ るためには立米のタンパク質等窒素化合物の含量を上げる ことが効果的であると予想されるので，追肥は幼穂形成期 より穂揃期に施用する方が望ましいと推測されるが，その 効果は必ずしも確認されなかった。また，米粒中の夕ンパ ク質含量を増大させることは食味を低下させることとな り，実用上では問題が大きい.

(3) 品種間差

2005 年〜2007 年, 早刈りや追肥による GABA 蓄積量の 増加について試みたが, GABA 蓄積量を劇的に増大させる ことはできなかった。

一方， 2005 年 4 時間水浸漬での GABA 蓄積量は，刈り 取り時期による差の大きい品種でもその差が 1.6 倍程度で あったのに比べ, 品種間差は 3 倍以上あった（表 1$)$.また, 2006 年, ベこごのみは水浸漬 4 時間後から 24 時間後の間 にもGABA 蓄積量が増大し続けたのに対し，ふくひびき は 4 時間後に蓄積していた GABA が 24 時間後には分解さ れているという品種的特徴がはっきりと確認された（表 
2).この品種による差異は2007 年の試験でも観察され, モミロマンは水浸漬 4 時間後から 24 時間後 GABA の蓄積 量が増大したのに対してべこあおばは 4 時間後に蓄積して いた GABA が 24 時間後に分解されていた（表 3).ささらに 2005 年と 2006 年の結果から，べこごのみでは 4 時間水浸 漬で約 $20 \mathrm{mg} / 100 \mathrm{~g}, 24$ 時間水浸漬で約 $40 \mathrm{mg} / 100 \mathrm{~g}$ とい うきわめて多量の GABA が蓄積する傾向があることが確 認された。

遺伝的背景の近い米品種においては GABA 蓄積量に大 きな差はなく，その蓄積量の変動も時間に対してどの品種 もほぼ同じ動きを示すが21，1994 年に行った肧芽を用いた 実験の結果 ${ }^{16)}$ や今回の実験結果のように，遺伝的背景の大 きく異なる米品種同士では GABA 蓄積量は大きく変動し, 一部の品種では長時間の水浸漬では一度蓄積した GABA が減少する場合があった。米肧芽は米粒の中で特に GABA の蓄積量が多い1)，そのため GABA を増加させるた めの専用米品種は，現在までのところ巨大胚芽米品種のみ で育成されてきた。それらの巨大胚芽米は，GABA 蓄積量 が多い（20４5 mg/100 g 程度 $\left.{ }^{13144}\right)$ が，大きな胚芽による 独特の食感が食味を低下させる傾向がある。しかし表 1〜3の結果から, GABA 蓄積量の多い品種を選抜する事 で，巨大胚芽米以外でも巨大胚芽米と同程度かそれ以上の GABA 蓄積が期待できる GABA 富化食品用の品種を育種 することも可能であることが示唆された

\section{3. 要 約}

4-アミノ酪酸（GABA）を蓄積させた玄米は，血圧低下 効果や精神安定作用が期待できるためにニーズが高い. GABA 蓄積加工用米として利用するために, 多様な遺伝背 景を持つ米で，早刈りや窒素追肥の効果を検討した。早刈 りによって GABA 蓄積量は増大しなかった。また，幼穂 形成期および穂揃期での窒素追肥によっても GABA 蓄積 量は必ずしも増大しなかった。しかし品種が異なると GABA 蓄積量は大きく変動し，一部（品種名べこごのみ） は $40 \mathrm{mg} / 100 \mathrm{~g}$ まで到達した。この結果は, 巨大胚芽米以 外にも GABA 富化食品用米品種の作出の可能性があるこ とを示唆している.

\section{文献}

1) Saikusa, T., Horino, T. and Mori, Y., Distribution of free amino acids in the rice kernel and kernel fractions and the effect of water soaking on the distribution. J. Agric. Food Chem., 42 1122-1125 (1994)

2) Baum, G., Lev-Yadun, S., Fridmann, Y., Arazi, T., Katsnelson, H., Zik, M. and Fromm, H., Calmodulin binding to glutamate decarboxylase is required for regulation of glutamate and GABA metabolism and normal development in plants. EMBO J., 15, 2988-2996 (1996).

3) Shelp, B.J., Bown, W. and McLean, M.D., Metabolism and functions of gamma-amino butyric acid. Trends plant Sci., 4, 446-452 (1999)

4) Kinnersley, A.M. and Turano, F.J., Gamma aminobutyric acid (GABA) and plant responses to stress. Crit. Rev. Plant Sci., 19, 479-509 (2000).

5) Stanton, H.C., Mode of action of gamma aminobutyric acid on the cardiovascular system. Arch. Int. Pharmacodyn. Ther., 143, 195-204 (1963).

6）岡田忠司，杉下朋子，村上太郎，村井弘道，三枝貴代，堀野 俊郎, 小野田明彦, 梶本修身, 高橋 励, 高橋丈夫, $\gamma-$ アミ ノ酪酸蓄積脱脂コメ胚芽の経口投与における更年期障害及 び初老期精神障害に対する効果, 日本食品科学工学会誌, 47, 596-603 (2000).

7）藤林真美, 神谷智康, 高垣欣也, 森谷敏夫, GABA 経口摂取 による自律神経活動の活性化, 日本栄養·食糧学会誌, 61, 129-133 (2008)

8）海老塚広子, 佐々木千恵, 喜瀬光男, 有田政信, 発芽玄米含 有レトルト米飯を摂取したときの健常人の栄養状態及び身 体状況に与える影響, 日本食生活学会誌, 18, 216-222 (2007).

9）杵淵美倭子, 関谷美由紀, 山㟝 涁, 山本皓二, 高圧処理を 利用した玄米中への $\gamma$-アミノ酪酸（GABA）の蓄積，日本 食品科学工学会誌， 46， 323-328 (1999).

10) Sasagawa, A., Naiki, Y., Nagashima, S., Yamakura, M., Yamazaki, A. and Yamada, A., Process for producing brown rice with increased accumulation of GABA using highpressure treatment and properties of GABA-increased brown rice. J. Appl.Glycosci., 53, 27-33 (2006).

11）山﨑 涁, 笹川秋彦, 高圧処理によるコメ加工食品の開発, 日本食品科学工学会誌， 45， 526-532 (1998).

12）佐竹利子, 福森 武, 劉 厚清, 河野元信, 佐々木泰弘, 高 機能性米の調製加工技術の開発 第 1 報 玄米の浸漬条件 が GABA 成分の生成等に及ぼす影響, 農業機械学会誌, $\mathbf{6 6}$, 115-121 (2004)

13）河野元信, 劉 厚清, 平井 敬, 水野英則, 飯田修一, 春原 嘉弘, 松下 景, 出田 収, 巨大胚米を用いた発芽米及び発 芽玄米の加工特性に関する研究，美味技術研究会誌，11, 25-28 (2008)

14）石井卓朗, 出田 収, 松下 景, 春原嘉弘, 前田英郎, 飯田 修一, 苗立ち性のすぐれる低アミロース巨大胚水稲品種「は いごころ」の育成，近畿中国四国農業研究センター研究報 告, 12, 25-41 (2013).

15）新井映子, 米の糖質分解酵素活性と米飯食味 早刈り米の おいしさの秘密とは, 応用糖質科学, 2, 203-207 (2012).

16) Saikusa, T., Horino, T. and Mori, Y., Accumulation of $\gamma$ aminobutyric acid (gaba) in the rice germ during water soaking. Biosci. Biotech. Biochem., 58, 2291-2292 (1994).

17）建部雅子, 及川 勉, 松野宏治, 清水恵美子, 米山忠克, 水 稲白米のグルテリン及びプロラミン含有率に対する窒素栄 養条件の影響, 日本土壤肥料学雑誌， 67，139-146 (1996).

18）平 宏和，多収穫栽培米のタンパク質含量に与える施肥の 影響, 日本作物学会紀事， 39，200-203 (1970).

19）藤井弘志, 安藤 豊, 松田裕之, 追肥時期および遮光処理に よる頴花生産効率の変化とそれが精米中のタンパク質含有 率に及ぼす影響, 日本土潩肥料学雑誌，69，463-469 (1998).

20）後藤英次, 野村美智子, 稲津 偹, 寒地水稲に対する時期別 追肥窒素の利用率と各器官への分配, 日本作物学会紀事, 75, 443-450 (2006).

21）呂 慶伝, 後藤清和, 西津貴久, 玄米の GABA 富化条件と 品質について，農業機械学会誌，72，291-296 (2010).

(平成 27 年 4 月 2 日受付, 平成 27 年 6 月 8 日受理) 